\title{
A STUDY OF AMERICAN MERCHANT MARINE LEGISLATION
}

\author{
Clarence G. Morse*
}

The main body of our national merchant marine legislation is found in the Merchant Marine Act of 1936 , as amended. ${ }^{1}$ However, that Act was preceded by other acts, some of whose provisions are still in effect as important parts of our merchant marine policy.

I

The First Comprehensive Program-the Shipping Act of igi6, as Aimended

The Shipping Act of $1916,{ }^{2}$ was designed to secure an American merchant marine which would be adequate for the needs of our national defense and our commerce, and to regulate competitive practices in ocean shipping for the protection of shippers, importers, exporters, carriers, and the public. The United States Shipping Board set up by the Act was authorized, with the approval of the President, ${ }^{3}$

to have constructed and equipped in American shipyards and navy yards or elsewhere, giving preference, other things being equal, to domestic yards, or to purchase, lease, or charter, vessels suitable, as far as the commercial requirements of the marine trade of the United States may permit, for use as naval auxiliaries or Army transports, or for other naval or military purposes, and to make necessary repairs on and alterations of such vessels.

The Board was further authorized, if unable to charter, lease, or sell to American citizens these and other vessels acquired by it, to form a corporation "for the purchase, construction, equipment, lease, charter, maintenance, and operation of merchant vessels in the commerce of the United States."

Another important feature of the Shipping Act of $\mathrm{rgr} 6$ is its regulatory provisions, which are operative today and are exercised by the Federal Maritime Board. Some aspects of this regulatory jurisdiction have been discussed in detail elsewhere in this symposium. ${ }^{6}$ These regulatory provisions prohibit common carriers by water from retaliating or unfairly or unjustly discriminating against shippers, and relate generally to the regulation and control of various rates, services, practices, and agree-

* B.S. 1926, J.D. 1928, University of California. Maritime Administrator and Chairman, Federal Maritime Board. Member of the California bar.

149 Stat. I985, as amended, 46 U.S.C. $\$ \$ 1$ ror-294 (1952).

39 Stat. 728,46 U.S.C. $\$ \S 801-42$ (1952).

39 Stat. 730 .

39 Stat. 731 .

39 Stat. 733-38, 46 U.S.C. $\$ \$ 812-3$ I (1952).

- Seaver \& Schmeltzer, The Role of Conferences and the Dual Rate System in Ocean Foreign Trade, 24 LaW \& Contemp. Prob. 605 (1959). 
ments of common carriers by water and of "other persons" as defined in the Act. Since the transfer by the Transportation Act of $1940^{7}$ of jurisdiction over water carriers in interstate commerce to the Interstate Commerce Commission, the regulatory jurisdiction over water carriers conferred by the Shipping Act of 1916 , as amended, upon the Shipping Board and its successors has been exercised only over carriers in American foreign or noncontiguous domestic trade.

Section two of the Shipping Act of $1916^{8}$ defines "citizen of the United States" for the purpose of that Act, and by reference ${ }^{\theta}$ defines it for the purposes of the Merchant Marine Act of $1920,{ }^{10}$ as amended, the Merchant Marine Act of 1936, as amended, and the Merchant Ship Sale Act of 1946 , as amended. ${ }^{11}$ It provides that no corporation, partnership, or association shall be deemed a citizen of the United States unless the controlling interest therein is owned by citizens of the United States, and, in the case of a corporation, unless its president or other chief executive officer and the chairman of its board of directors are citizens of the United States and unless no more of its directors than a minority of the number necessary to constitute a quorum are noncitizens and the corporation itself is organized under the laws of the United States. or of a State, Territory, District, or possession thereof, but in the case of a corporation, association, or partnership operating any vessel in the coastwise trade the amount of interest required to be owned by citizens of the United States shall be 75 per centum.

It further provides that the "controlling interest" or "75 per centum interest" requirements will apply to legal title, beneficial interest, voting power, and actual control. The Eighty-fifth Congress ${ }^{12}$ enacted somewhat less strict "citizenship" standards to apply under certain circumstances (overriding the I9r6 Act's definition in those instances) with respect to section twenty-seven of the Merchant Marine Act of ${ }^{x} 920^{13}$ (cargo transport in domestic trade), and sections nine and thirty-seven of the Shipping Act of I9I6, as amended (transfer to foreign flag, ownership, or control). ${ }^{14}$

These last-named provisions of the Shipping Act of 1916 , as amended, are currently of special importance. Section nine generally prohibits any sale, mortgage, lease, charter, delivery, or other transfer to a person not an American citizen or the placing under foreign flag or registry of any vessel or any interest therein owned wholly or partly by an American citizen and documented under the laws of the United States without the approval of the Maritime Administration. Section thirtyseven is a broader provision of a similar nature, only effective when the United' States is at war or during a national emergency proclaimed by the President, which

${ }^{3} 54$ Stat. 950,49 U.S.C. $\$ 920$ (1952).

839 Stat. 729 , as amended, ${ }_{46} 6$ U.S.C. $\$ \S 802,803$ (1952).

94 Stat. 2016 (1936), 46 U.S.C. $\$ 888$ (1952); 66 Stat. $765,{ }_{4} 6$ U.S.C. $\$ 1244$ (c) (1952); 64 Stat. 1276, 1277 (1950), 50 U.S.C. App. $\$ 1736(\mathrm{~g})$ (1952). But with reference to a corporation under title XI of the 1936 Act, all directors must be United States citizens. 73 Stat. 597 (1959).

${ }_{10}^{10} 4 \mathrm{I}$ Stat. 988,46 U.S.C. $\$ \S 86 \mathrm{I}-89$ (1952).

${ }^{21} 60$ Stat. 4I, 50 U.S.C. App. $\$ 1735-46$ (1952).

1272 Stat. $1736,{ }_{4} 6$ U.S.C.A. $\$ 883^{-1}$ (Supp. 1958).

${ }_{18}^{18} 4$ S Stat. 999,46 U.S.C. $\$ 883$ ( 1952 ).

14 39 Stat. 730,46 U.S.C. $\$ 808$ (1952); 40 Stat. 901 (1918), 46 U.S.C. $\$ 835$ (1952). 
additionally extends to shipyards, dry-docks, ship-building or ship-repairing facilities, and ship-construction contracts.

The Maritime Administration, in approving the transfer of a vessel to a foreign owner or foreign flag under these provisions, considers the need for retention of the vessel involved under the American flag or American ownership, and also considers the extent to which the United States will have effective control over the transferred vessel or the foreign owner. Type, size, speed, general condition, and age of the vessel, as well as the acceptability of the prospective foreign buyer or foreign flag are all taken into account. The important considerations are national defense, maintenance of an adequate American merchant marine, American foreign policy, and the national interest. Generally the approval of the transfer to a foreign flag or owner is not granted as to a large American-flag vessel under twenty years of age unless the American transferring owner agrees to replace the transferred vessel or vessels by the construction of a new vessel or vessels in an American shipyard for American documentation and operation, the new ship or ships to be of size, type, design, speed, and carrying capacity acceptable to the Maritime Administrator. In permitting American ships to be transferred to foreign ownership and registry, the Maritime Administration, in some cases, imposes other conditions on the owner of the foreign-flag ship and on the ship itself which are designed to retain for the United States a certain measure of "effective control" over such ship, in order that it may be available to the United States in the event of national emergency.

II

\section{The Next Step-Private Operation of Wordd War I Fleet under the Merchant Marine Act of rg20, as Amended}

One of the primary purposes of the Merchant Marine Act of rg20 was to sell, to American citizens if possible, the large fleet of World-War-I-built merchant ships then in the hands of the Government. In addition, the Act declared it to be national policy to develop and maintain a sufficient American merchant marine "ultimately to be owned and operated privately by citizens of the United States."15 Section seven of this Act provided that, ${ }^{16}$

the Board is authorized and directed to inyestigate and determine as promptly as possible after the enactment of this Act and from time to time thereafter what steamship lines should be established and put in operation from ports in the United States or any Territory, District, or possession thereof to such world and domestic markets as in its judgment are desirable for the promotion, development, expansion, and maintenance of the foreign and coastwise trade of the United States and an adequate postal service, and to determine the type, size, speed, and other requirements of the vessels to be employed upon such lines and the frequency and regularity of their sailings, with a view to furnishing adequate, regular, certain, and permanent service.

${ }^{16} 4$ I Stat. 988,46 U.S.C. $\$ 861$ (1952).
${ }_{10}$ 4I Stat. 991,46 U.S.C. $\$ 866$ (I952). 
The Board is authorized to sell, and if a satisfactory sale cannot be made, to charter such of the vessels . . . acquired by the board, as will meet these requirements to responsible persons who are citizens of the United States who agree to establish and maintain such lines upon such terms of payment and other conditions as the Board may deem just and necessary to secure and maintain the service desired; and if any such steamship line is deemed desirable and necessary, and if no such citizen can be secured to supply such service by the purchase or charter of vessels on terms satisfactory to the board, the board shall operate vessels on such line until the business is developed so that such vessels may be sold on satisfactory terms and the service maintained, or unless it shall appear within a reasonable time that such line cannot be made self-sustaining. . . .

Other major provisions of the Merchant Marine Act of 1920 were sections eleven and twenty-four. ${ }^{17}$ Section eleven provided that,

during a period of five years from the enactment of this Act the board may annually set aside out of the revenues from sales and operations a sum not exceeding $\$ 25,000,000$, to be known as its construction loan fund, to be used in aid of the construction of vessels of the best and most efficient type for the establishment and maintenance of service on steamship lines deemed desirable and necessary by the board, and such vessels shall be equipped with the most modern, the most efficient, and the most economical machinery and commercial appliances. The board shall use such fund to the extent required upon such terms as the board may prescribe to aid persons, citizens of the United States, in the construction by them in private shipyards, in the United States of the foregoing class of vessels. No aid shall be for a greater sum than two-thirds of the cost of the vessel or vessels to be constructed, and the board shall require such security, including a first lien upon the entire interest in the vessel or vessels so constructed as it shall deem necessary to insure the repayment of such sum with interest thereon and the maintenance of the service for which such vessel or vessels are built.

\section{Section twenty-four provided that,}

all mails of the United States shipped or carried on vessels shall, if practicable, be shipped or carried on American-built vessels documented under the laws of the United States. No contract hereafter made with the Postmaster General for carrying mails on vessels so built and documented shall be assigned or sublet, and no mails covered by such contract shall be carried on any vessel not so built and documented. No money shall be paid out of the Treasury of the United States on or in relation to any such contract for carrying mails on vessels so built and documented when such contract has been assigned or sublet or when mails covered by such contract are in violation of the terms thereof carried on any vessel not so built and documented. The board and the Postmaster General, in aid of the development of a merchant marine adequate to provide for the maintenance and expansion of the foreign or coastwise trade of the United States and of a satisfactory postal service in connection therewith, shall from time to time determine the just and reasonable rate of compensation to be paid for such service, and the Postmaster General is hereby authorized to enter into contracts within the limits of appropriations made therefor by Congress to pay for the carrying of such mails in such vessels at such rate.

Parts of the Merchant Marine Act of 1920 , as amended, are still in effect. These effective provisions include section thirty of the Ship Mortgage Act of $1920,{ }^{18}$ which

${ }^{17} 4$ I Stat. 993 (repealed June 29, 1936); 4 I Stat. 998,46 U.S.C. $\$ 880$ (1952).

${ }_{4}^{18}$ I Stat. I000, 46 U.S.C. $\$ 9$ Ir (1952). 
establishes the requirements and effects of a "preferred mortgage," and section twentyseven, ${ }^{10}$ which generally prohibits the transportation by water of merchandise between points in the United States, its districts, territories, and possessions in any vessel other than one built in and documented under the laws of the United States and owned by persons who are American citizens. A similar provision prohibits the transportation of passengers between ports or places in the United States in a foreign vessel. ${ }^{20}$ Under section nineteen of the ${ }^{2} 920 \mathrm{Act}{ }^{21}$ the $\mathrm{FMB}$ is authorized to make certain rules and regulations affecting shipping in the foreign trade and to take action to secure the approval, suspension, modification, or annulment of certain rules or regulations of other federal agencies affecting shipping in the foreign trade.

\section{III}

The Merchant Marine Act of i928-Broadened Existing Statutes

The Merchant Marine Act of $1928^{22}$ increased the size of the construction loan fund provided for by the Merchant Marine Act of r920; enabled loans to be made therefrom for equipping, reconditioning, remodeling, or improving vessels as well as for constructing vessels; and raised the loan limitation from two-thirds of the cost of the vessel to be constructed to three-fourths of the cost of the vessel construction, equipment, reconditioning, remodeling, or improvement. The I928 Act further provided that officers or employees of the United States traveling on official business overseas shall travel on American-flag ships when available.

The Merchant Marine Act of $x_{928}$ also broadened the ocean-mail provisions of the Merchant Marine Act of $x 920$ by authorizing the Postmaster General to enter into contracts with American citizens for terms not to exceed ten years. A statutory schedule of vessel classifications and compensation was set out to apply to payments for ocean-mail service. For instance, vessels capable of maintaining a speed of eighteen knots at sea in ordinary weather and of a gross registered tonnage of not less than 12,000 tons were Class 3 vessels and entitled to eight dollars per nautical mile; vessels capable of maintaining a speed of twenty knots at sea in ordinary weather and of a gross registered tonnage of not less than 16,000 tons were Class 2 vessels and entitled to ten dollars per nautical mile for providing ocean-mail service. In addition, the ocean-mail contracts authorized under the I928 Act provided for a fixed minimum number of trips a year, at regular intervals, over a prescribed route, with vessels of prescribed types, sizes, and speeds, as determined by the needs of each particular service. Vessels, to be eligible for mail contracts, had either to be constructed according to plans and specifications approved by the Secretary of the Navy with particular reference to economical conversion into an auxiliary

${ }^{10} 4$ I Stat. 999, 46 U.S.C. $\$ 883$ (1952).

2024 Stat. 8I (I886), as amended, 46 U.S.C. \$ 289 (r952).

${ }^{21} 4$ I Stat. 995,46 U.S.C. $\$ 876$ (I952).

2245 Stat. 689,46 U.S.C. $\$ 89$ I (1952). 
naval vessel, or to be otherwise useful to the United States in time of national emergency. Section $405(\mathrm{c})$ of the 1928 Act further provided that ${ }^{23}$

... from and after the enactment of this Act ... and for a period for four years, upon each departure from the United States of a vessel employed in ocean mail service under this title, one-half of the crew (crew including all employees of the ship other than officers) shall be citizens of the United States and, thereafter, two-thirds of the crew as above defined shall be citizens of the United States.

Further requirements of the Merchant Marine Act of 1928 were that vessels receiving loans from the construction loan fund or in respect of which ocean-mail contracts were made were obligated to remain documented under the American flag for not less than twenty years. These vessels were also subject to being taken and purchased or used by the United States for national defense or during any national emergency declared by proclamation of the President; and in such event, the owner would be paid only the fair actual value of the vessel or use at the time of the taking, without either enhancement by the causes necessitating the taking or any consequential damages.

\section{IV \\ The "Magna Carta" of the Amertcan Merchant Mardne-}

The Merchant Marine Act of 1936

On March 4, 1935, the President sent to Congress a merchant marine message that stated $:^{24}$

I present to the Congress the question of whether or not the United States should have an adequate merchant marine.

To me there are three reasons for answering this question in the affirmative. The first is that in time of peace subsidies granted by other nations, shipping combines, and other restrictive, or rebating methods may well be used to the detriment of American shippers. The maintenance of fair competition alone calls for American flagships of sufficient tonnage to carry a reasonable portion of our foreign commerce.

Second, in the event of a major war in which the United States is not involved, our commerce, in the absence of an adequate American merchant marine, might find itself seriously crippled because of its inability to secure bottoms for neutral peaceful foreign trade.

Third, in the event of a war in which the United States itself might be engaged, American flagships are obviously needed not only for naval auxiliaries, but also for the maintenance of reasonable and necessary commercial intercourse with other nations. We should remember lessons learned in the last war.

In many instances in our history the Congress has provided for various kinds of disguised subsidies to American shipping. In recent years the Congress has provided this aid in the form of lending money at low rates of interest to American shipping companies for the purpose of building new ships for foreign trade. It has, in addition, appropriated large annual sums under the guise of payments for ocean-mail contracts.

${ }^{23} 45$ Stat. 693 (repealed June 29, 1936).

is Message from President of the United States Transmitting Views and Two Reports on Subject of Adequate Merchant Marine, H.R. Doc. No. I18, 74th Cong., Ist Sess. 1-3 (1935). 
This lending of money for shipbuilding has in practice been a failure. Few ships have been built and many difficulties have arisen over the repayment of the loans. Similar difficulties have attended the granting of ocean-mail contracts. The Government today is paying annually about $\$ 30,000,000$ for the carrying of mails which would cost, under normal ocean rates, only $\$ 3,000,000$. The difference, $\$ 27,000,000$, is a subsidy, and nothing but a subsidy. But given under this disguised form it is an unsatisfactory and not an honest way of providing the aid the Government ought to give to shipping.

I propose that we end this subterfuge. If the Congress decides that it will maintain a reasonably adequate American merchant marine, I believe that it can well afford honestly to call a subsidy by its right name.

Approached in this way a subsidy amounts to a comparatively simple thing. It must be based upon providing for American Shipping government aid to make up the differential between American and foreign shipping costs. It should cover first the difference in the cost of building ships; second, the difference in the cost of operating ships; and finally, it should take into consideration the liberal subsidies that many foreign governments provide for their shipping. Only by meeting this threefold differential can we expect to maintain a reasonable place in ocean commerce for ships flying the American flag, and at the same time maintain American standards. ...

An American merchant marine is one of our most firmly established traditions. It was, during the first half of our national existence, a great and growing asset. Since then it has declined in value and importance. The time has come to square this traditional ideal with effective performance.

Free competition among the nations in the building of modern shipping facilities is a manifestation of wholly desirable and wholesome national ambition. In such free competition the American people want us to be properly represented. The American people want to use American ships. Their Government owes it to them to make certain that such ships are in keeping with our national pride and national needs.

In response to the President's message, Congress enacted the Merchant Marine Act of 1936. This Act, as amended, still forms the basic legislation for effectuating our national merchant marine policy. That policy, which is set out in section roI of the Act, states: $:^{25}$

It is necessary for the national defense and development of its foreign and domestic commerce that the United States shall have a merchant marine (a) sufficient to carry its domestic water-borne commerce and a substantial portion of the water-borne export and import foreign commerce of the United States and to provide shipping service on all routes essential for maintaining the flow of such domestic and foreign water-borne commerce at all times, (b) capable of serving as a naval and military auxiliary in time of war or national emergency, (c) owned and operated under the United States flag by citizens of the United States insofar as may be practicable, and (d) composed of the bestequipped, safest, and most suitable types of vessels, constructed in the United States and manned with a trained and efficient citizen personnel. It is declared to be the policy of the United States to foster the development and encourage the maintenance of such a merchant marine.

This statement recognizes that aside from national defense, the entire American economy benefits from the maintenance of a healthy merchant marine. The United

${ }_{49}^{25}$ Stat. 1985,46 U.S.C. $\S$ Irox (1952). 
States could not maintain its position of world leadership if the flow of foreign commerce were severely restricted or eliminated. Without an American-flag merchant fleet, American traders would be at the mercy, commercially, of foreign-flag lines. An adequate American fleet can only be maintained through government aid of various kinds.

Another important aspect of our merchant marine policy which is recognized in various provisions of the Merchant Marine Act of 1936 and in other legislation is the encouragement and maintenance of sufficient American shipyards, ship-building facilities, ship-repairing facilities, and skilled shipyard personnel to carry out the purposes and policies of the Act and to provide an adequate mobilization base at strategic points for purposes of national defense and national emergency. Section $502(\mathrm{f})$ of the Act, for example, authorizes the FMB to allocate construction projects on this mobilization basis. ${ }^{26}$

To carry out the policies and provisions of the Merchant Marine Act of 1936 , section 201 established the United States Maritime Commission, ${ }^{27}$ and section 204 transferred to the Commission all the functions, powers, and duties vested in the United States Shipping Board by the Shipping Act of 1916, the Merchant Marine Act of 1920 , and the Merchant Marine Act of $1928 .{ }^{28}$ The United States Maritime Commission was abolished by Reorganization Plan 21 of $1950,{ }^{29}$ effective May 24, I950. The plan established the Maritime Administration and the FMB as agencies in the Department of Commerce, and all the functions of the Maritime Commission and its chairman were transferred under the plan to the Secretary of Commerce, except those specifically placed under the jurisdiction of the FMB. The Secretary of Commerce may delegate any or all of his functions authorized under the reorganization plan to the Maritime Administrator, which he has since done. Reorganization Plan 2I also provided that the FMB Chairman, who is designated by the President, shall be the Maritime Administrator, and thus he serves in a dual capacity.

The Maritime Administrator investigates and determines ocean services, routes, and lines essential for the development and maintenance of American foreign commerce; and the type, size, speed, and other requirements of ships which should be employed on such routes or lines, and the frequency and regularity of sailings of such vessels required to provide adequate service on such routes. The FMB finds the extent and character of aids and subsidies granted by foreign governments to their merchant marines, and determines construction and operating-differential subsidies on the basis of the comparative cost of construction and operation of ships in the United States and in foreign countries, subject to the limitations of the Merchant Marine Act of 1936 .

\footnotetext{
${ }^{26} 49$ Stat. 1996, 46 U.S.C. $\$$ II52(f) (1952).

${ }^{27} 49$ Stat. 1985, 46 U.S.C. \$ IIII (1952).

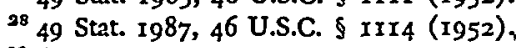

2064 Stat. 1273 .
} 
The Maritime Administration administers the provisions of all subsidy contracts of the FMB. It also aids in the construction, reconditioning, and reconstruction of ships by insuring private construction loans and mortgages made to finance the construction or conversion of American ships; makes payment of the cost, as determined by the FMB, of national defense features added to ships; and acquires obsolete ships in exchange for allowances of credit on the construction of new ships.

\section{V}

Aids for Construction-Titue Five of the Merchant Marine Act of 1936

\section{A. Construction Subsidy}

The general purpose of the construction differential subsidy provisions of title five of the Merchant Marine Act of $193^{60}$ is to place the American-built and operated ship in a position of parity with its foreign competitors, in so far as the cost of the ship is concerned. This assistance is granted in recognition of the fact that the American-flag operator of an American-built ship in the foreign commerce of the United States is at a capital disadvantage compared with the foreign-built ship of his foreign competitor. The higher wages and prices in the United States account for the higher cost of American-built ships. The construction-differential subsidy makes it possible for the American operator to acquire an American-built ship at a price for which he could purchase his ship in a foreign shipyard. In one sense, this program actually provides the subsidy for the American shipyards.

Sections 501, 502, and 504 of the Merchant Marine Act of 1936 authorize the FMB to grant a construction-differential subsidy aid to American citizens in the construction of new vessels to be used in the foreign commerce of the United States. ${ }^{31}$ While under the act as passed in 1936 such aid was limited to vessels to be used on an essential service, route, or line in American foreign commerce, amendments adopted in 1952 authorized the granting of such aid in connection with the construction of any vessel to be used in American foreign commerce. ${ }^{32}$

This construction-differential-subsidy aid may equal but not exceed the difference between the cost of constructing the proposed vessel in an American shipyard and the fair and reasonable estimate of cost, as determined by the Board, of the construction of the proposed vessel, using similar plans and specifications, in a foreign shipbuilding center. The construction-differential subsidy cannot exceed fifty per cent of the American construction cost of the vessel (excluding the cost of national-defense features). As the disparity between American and foreign costs increases, the subsidy has approached nearer and nearer this limit; in I959, the subsidy was approximately forty-eight per cent for the construction of a new vessel.

The cost of national defense features is determined by the Board and paid by the Government in addition to the subsidy. National defense features are those which

${ }^{80} 49$ Stat. 1995,46 U.S.C. $\$ \$$ Ir 5 I-6I (1952).

3149 Stat. $1995,1996,1998,46$ U.S.C. $\$ 1151,1152,1154$ (1952).

3249 Stat. 2001 , as amended, 66 Stat. 765,46 U.S.C. $\$$ Ir $71-82$ (1952). 
are certified by the Secretary of the Navy as useful for national defense purposes and which are determined by the Board to be either in, excess. of commercial requirements or disproportionate in cost to their commercial utility. The plans and specificttions of the proposed vessel must receive Navy Department approval to ensure that it will be suitable for economical and speedy conversion into a naval or military auxiliary, or otherwise suitable for the use of the United States Government in time of war or national emergency.

In approving applications for construction-differential subsidy aid, section 50r of the Merchant Marine Act of I936 requires that the Board determine that: (I) the plans and specifications call for a new vessel which will meet the requirements of American foreign commerce, will aid in the promotion and development of such commerce, and will be suitable for national defense or military purposes in time of war or national emergency; (2) the applicant possesses the ability, experience; financial resources, and other qualifications to operate and maintain the proposed vessel; and (3) the granting of the aid is reasonably calculated to replace worn or obsolete tonnage with new and modern ships, or otherwise carry out effectively the purposes and policies of the Act.

Construction-differential subsidy aid may also be 'granted in connection with the reconstruction or reconditioning of an existing vessel that is to be used in the foreign commerce of the United States. However, this aid may be granted only' in exceptional cases, after thorough study and a formal determination that the proposed reconstruction or reconditioning is consistent with the purposes and policies of the Merchant Marine Act of 1936 .

Under sections 503 and 504 of the Merchant Marine Act of 1936, any vessel with respect to which a differential subsidy is granted must remain documented under the laws of the United States for not less than twenty years or so long as any principal or interest on account of the purchase price is due the United States, whichever is the longer period. ${ }^{33}$ Section 506 of the Act provides that every owner of a vessel for which a construction-differential subsidy has been paid must agree that the vessel shall be operated in foreign trade or on a round-the-world voyage, and that if the vessel is operated in the domestic trade, he will pay annually to the Board such portion of one-twentieth of the construction-differential subsidy paid for the vessel as the gross revenue derived from the domestic trade bears to the gross revenue from the entire voyages completed during the preceding year. ${ }^{34}$ The Board may allow domestic use of such a vessel for periods not exceeding six months in any year, but the owner must pay to the Board an amount which bears the same proportion to the construction-differential subsidy paid for such vessel as such temporary period bears to the entire economic life of the vessel.

Under the provisions of sections 802 and 902 of the Merchant Marine Act of 1936 , vessels upon which a construction-differential subsidy has been paid may be pur-

${ }^{38} 49$ Stat. 1997-98, 46 U.S.C. $\$ \$ . I I 53$, II 54 (1952).

${ }^{34} 49$ Stat. 1999, 46 U.S.C. \$.1156:(1952). 
chased or requisitioned by the United States during a national emergency or when the security of the national defense makes it advisable. ${ }^{35}$ In such a case, the payment to the owner cannot exceed the actual depreciated construction cost of the vessel (together with the actual depreciated cost of capital improvements thereon, but excluding the cost of national defense features), less the depreciated amount of construction-differential subsidy paid on the vessel, or the fair and reasonable scrap value of such vessel as determined by the Board, whichever is the greater.

Section 505 of the Merchant Marine Act of 1936 provides that all construction in respect of which a construction-differential subsidy is allowed must be performed in a shipyard within the continental limits of the United States, following competitive bidding, after due advertisement. ${ }^{36}$ In all such construction, the ship-builder, subcontractors, materialmen, and suppliers must use, so far as practicable, only articles, materials, and supplies of the growth, production, or manufacture of the United States. Sections 502 and 509 of the Act allow Pacific coast shipyards a six per cent margin over Atlantic and Gulf coast shipyards in competitive bidding involving the construction or reconditioning of a vessel to be operated from the Pacific coast of the United States for an applicant who has his principal place of business on the Pacific coast of the United States. ${ }^{37}$ In addition, upon the basis of a finding that the award of the proposed construction, reconstruction, reconditioning, or remodeling work will remedy an existing inadequacy in our national defense mobilization base as to the capabilities and capacities, including facilities and skilled personnel, of a shipyard or shipyards for merchant ship construction, section 502 allows, with the approval of the President, allocation of the work to such yard or yards, without regard to the provisions requiring awarding of contracts to the lowest bidder.

In connection with the granting of construction-differential subsidy, section 502 of the Act further provides for FMB construction of the vessel. In such a situation, the Board pays to the shipyard the contract price of the ship and an appropriation is made by Congress for the full cost of the ship. The ship is then sold by the Board to the American operator at a price equal to the estimated foreign cost of the ship. The purchaser pays twenty-five per cent of the sales price, with the balance secured by a mortgage, payable in twenty equal annual installments, at an interest rate of 3.5 per cent. A similar procedure is followed under section 509 of the Act, which authorizes aid in the form of payment for national defense features (without a construction-differential subsidy) for new vessels to be operated in the foreign or domestic trade. These provisions have not been used in recent years, however, as private financing has been favored.

Another means by which the Board may enter into contracts with purchasers for the building of new ships is provided by section 504 of the Merchant Marine Act of 1936 , under which construction-differential aid may be granted for the construction of a ship by an American shipyard for the direct account of an American

\footnotetext{
${ }^{35} 49$ Stat. $2011,2015,46$ U.S.C. $\$ \$ 1212$, 1242 (1952).

${ }^{30} 49$ Stat. 1998,46 U.S.C. $\$$ II 55 (1952).

${ }^{37} 49$ Stat. I996, 2000, 46 U.S.C. $\$ \$$ II52, II59 (1952).
} 
operator. In such a.case, the operator is responsible for the payments to the shipbuilder and for the financing of the cost of the ship to him. The Government pays only the construction subsidy aid and does not provide mortgage financing for the balance of the cost. Accordingly, smaller appropriations by the Congress are required. For this reason, and since recent amendments to title eleven of the Act (discussed below) ${ }^{38}$ have facilitated private financing of the operator's purchase price, this latter method of financing the ship construction costs of the operator is currently preferred.

\section{B. Trade In}

Sections 507 and 5 ro of the Merchant Marine Act of 1936 as amended, provide the statutory authorities for the trade-in of old ships to the Government as an inducement to the owners to replace such ships through new construction. Section 507 authorizes the acceptance of obsolete vessels as a trade-in, in part payment for a replacement vessel to be constructed and sold to the owner under title five of the Act. ${ }^{30}$ This section, in effect, establishes the book value of the ship to the owner or its former owner as the basic factor to be considered in determining the amount of allowance for the traded-in ship. It was found that section 507 did not have the desired effect, and that old and obsolete tonnage was being continued in operation, to the detriment of the merchant marine program. As a result, there was added to the Act in 1939 section 510, which established a new principle for determining the allowance of credit for a traded-in ship. ${ }^{40}$ It requires consideration of three factors in determining a fair and reasonable value-namely, the scrap value of the obsolete vessel both in American and foreign markets, the depreciated value based on a twenty-year life, and the market value of the obsolete vessel for operation in world trade or in the foreign or domestic trade of the United States. Section 5ro allows trade-in credit towards both new ships constructed under the provisions of the Merchant Marine Act of 1936 and new ships otherwise constructed in American shipyards for private account and documentation under the American flag. Section 510 as originally enacted provided that "obsolete vessels" could not be less than seventeen years old; later legislation, however, effective only until June 30 , 1962, has redefined the term "obsolete vessel" so as to make twelve-year-old vessels eligible for trade-in." If the owner of the obsolete vessel uses such vessel during the period of construction of the new vessel, the trade-in allowance is reduced by an amount representing the fair value of such use.

Ships traded in to the Government are placed in the National Defense Reserve Fleet. This fleet was created by section eleven of the Merchant Ship Sales Act of $1946^{42}$ and also contains war-built government vessels not sold under the provisions of that Act. The primary purpose of the reserve fleet, as established by law, is to

${ }^{38} 52$ Stat. 968 (1938), 66 Stat. 765 (1952), 46 U.S.C. $\$ 1271-79$ (1952); sec pt vii infra.

so 49 Stat. 2000, 46 U.S.C. $\$ \$ 1157$ (1952).

1053 Stat. $18_{3}$ (1939), 46 U.S.C. $\$ 1160$ (1952).

466 Stat. 762 (1952), 72 Stat. I7, 46 U.S.C. $\$ 1160$. (Supp. 1958).

${ }^{42} 60$ Stat. 49 , 50 U.S.C. App. \$1744 (I952). 
provide, after consultation with the appropriate military authorities, a reserve of vessels of sufficient value for commercial and national defense purposes to warrant their maintenance and preservation. It is prescribed that unless otherwise provided for by law, all vessels placed in such reserve are to be preserved and maintained for the purposes of national defense. The suitability with respect to size, composition, and speed of the reserve fleet for military purposes is determined jointly by the Maritime Administration and the Navy, based on an annual statement of requirements from the Joint Chiefs of Staff. In addition, the reserve fleet provides a reservoir of useful tonnage to meet special governmental and commercial requirements. Today there are approximately 2,090 vessels at eight fleet sites located at various points around the three coasts.

Section eleven of the Merchant Ship Sales Act of 1946 provides that reserve fleet vessels may be operated "for account of any agency or department of the United States" during periods of national emergency. ${ }^{43}$ Section $5(\mathrm{e})$ of the Act, as amended, further provides that reserve fleet dry cargo vessels may be chartered on bareboat terms to American citizens for services which, in the opinion of the FMB, are required in the public interest, are not adequately served, and for which privatelyowned American-flag vessels are not available for charter by private operators on reasonable conditions and at reasonable rates. ${ }^{44}$

Section $5 \mathrm{ro}(\mathrm{h})$ of the Merchant Marine Act of 1936 , the tanker trade-in-and-build program, which was enacted in 1954 and which expired on July I, 1958 , authorized the Secretary of Commerce to acquire tankers not less than ten years old in exchange for an allowance of credit towards the purchase of a new American-flag tanker. ${ }^{45}$ The purpose of this program was to obtain tankers desirable for inclusion in the national defense reserve for use in the event of a national emergency and also to promote the private construction of new tankers in line with national defense requirements.

\section{Tax Advantages-The Construction Reserve Fund}

Any American operator in the foreign or domestic commerce of the United States is authorized under section 5 II of the Merchant Marine Act of 1936, as amended, to establish a construction reserve fund. ${ }^{46}$ In this fund, the operator may deposit (a) proceeds from the sale of ships, (b) indemnities for the loss of ships, (c) earnings derived from the operation of ships documented under the laws of the United States, and from services incident to such operation, and (d) interest or other earnings upon amounts previously deposited. Since section 607 of the Act requires an operator in American foreign commerce who is receiving an operating-differential subsidy to establish a "capital reserve fund" and a "special reserve fund;" operators do not establish construction reserve funds. As to the deposit of proceeds

is lbid.

14 64 Stat. 308 (1950), 50 U.S.C. App. $\$ 1738$ (c) (1952).

${ }^{10} 68$ Stat. 680 (1954), 46 U.S.C. $\$$ II6o(h) (Supp. V, 1958).

${ }^{10}{ }_{54}$ Stat. 1106 (1950), ${ }_{46} 6$ U.S.C. \$ II6r (x952).

47 Stat. 2005, 46 U.S.C. $\$ 1177$ (1952): 
from the sale of a ship or proceeds from insurance on a lost ship, the operator who establishes a construction reserve fund may elect in his federal income tax returns to treat any gain on such sale or insurance recovery as not recognized. However, in such a case, the tax basis of vessels acquired or improved with money from the construction reserve fund is reduced by an amount equal to the unrecognized gain; and since ordinary income is now taxed at higher rates than long-term capital gains, it is usually not advantageous taxwise to make the election permitted by section $5 \mathrm{II}$, in light of the fact that deductions for depreciation (offsets against ordinary income) on the new vessel will be accordingly reduced. As to the deposit of earnings derived from the operation of ships and service incidental thereto and the interest or earnings upon amounts deposited, no tax benefits are afforded other than an exemption from the prohibition of the Internal Revenue Code against unreasonable accumulation of funds. In order to secure the tax deferral on gain from the sale of ships or insurance on lost ships, the moneys deposited in the construction reserve fund must be used within a specified time for the acquisition of a new ship, in the reconditioning or reconstruction of a ship, or in the liquidation of indebtedness covered by a purchase money mortgage on a new vessel. If the moneys deposited in the fund are not used as indicated above within the prescribed time, or if they are withdrawn for other purposes, the amount of the untaxed gain is taxable as of the year in which realized and the exemption from the prohibition against unreasonable accumulation of funds no longer applies.

\section{VI}

Aids for Operation-Titre Six of the Merchant Marine Act of 1936

Because of the differences between certain American-flag and foreign-flag operating costs, especially for labor, it is necessary to provide operators of liner ships registered under United States laws with subsidies sufficient to place them in a position of approximate cost parity with their foreign competitors. Section 6or of the Merchant Marine Act of 1936 authorizes the FMB to consider the applications of citizens of the United States for financial aid in the operation of vessels on essential American foreign-trade routes. ${ }^{48}$ No such application may be approved by the Board unless it finds that: ( $\mathrm{I}$ ) the operation of such vessel or vessels in such essential service, route, or line is required to meet foreign-flag competition and to promote American foreign commerce, and the vessels were built in the United States; (2) the applicant owns, or can and will build or purchase, vessels of the size, type, speed, and number and with the proper equipment required to enable him to operate and maintain the service, route, or line in such manner as may be necessary to meet competitive condiditions and to promote American foreign commerce; (3) the applicant possesses the ability, experience, financial resources, and other qualifications necessary to enable him to conduct the proposed operations of the vessels so as to meet competitive conditions and promote American foreign:; commerce; and (4) the granting of the

${ }^{48} 49$ Stat. $200 \mathrm{r}, 46$ U.S.C. $\$$ II7I (1952). 
aid is necessary to place the proposed operation of the vessels on a parity with those of foreign competitors and is reasonably calculated to carry out effectively the purposes and policies of the Act.

With regard to trade routes, section 2II of the Merchant Marine Act of 1936 authorizes and directs the Maritime Administrator to investigate, determine, and keep current records of ${ }^{49}$

the ocean services, routes, and lines from ports in the United States . . . to foreign markets, which are, or may be . . . essential for the promotion, development, expansion, and maintenance of the foreign commerce of the United States ... [the Maritime Administration] shall consider and give due weight to ... the number of sailings and types of vessels that should be employed in such lines and any other facts and conditions that a prudent businessman would consider when dealing with his own business, with the added consideration, however, of the intangible benefit the maintenance of any such line may afford to the foreign commerce of the United States and the national defense.

Thirty-three trade routes and three services are currently designated as essential in American foreign commerce.

Under section 603, of the Merchant Marine Act of 1936, the FMB may approve an application to serve an essential trade route and enter into a long-term operating subsidy contract, not to exceed twenty years, with the applicant. ${ }^{50}$ The operator agrees to furnish adequate and regular service, as provided in the contract. The contract does not guarantee subsidized operators a profit. It is designed to insure continuity of service on the route and contains an agreement by the operator to replace obsolete vessels with modern vessels constructed in American shipyards. The Board agrees to pay an operating-differential subsidy equal to

the excess of the fair and reasonable cost of insurance, maintenance, repairs not compensated by insurance, wages, and subsistence of officers and crews, and any other items of expense in which the ... [Board] shall find and determine that the applicant is at a substantial disadvantage in competition with vessels of the foreign country hereinafter referred to, in the operation under United States registry of the vessel or vessels covered by the contract, over the estimated fair and reasonable cost of the same items of expense . . . if such vessels were operated under the registry of a foreign country whose vessels are substantial competitors of the vessels covered by the contract.

Payments are determined and stated as percentages of certain specified subsidizable expenses of an American operator. Separate rates are determined for each type of such expense for each type of vessel on each trade route, after taking into consideration each principal foreign-flag competitor. The process of calculating these rates is complex and requires a large amount of foreign-cost information which must be maintained on a current basis.

There are many conditions attached to the granting of an operating-differential subsidy. A subsidy will not be paid on account of the operation of any vessel which has not been built in a domestic yard. In addition, the vessel must be constructed

${ }^{40} 49$ Stat. I989, 46 U.S.C. $\$$ II2I (I952).

${ }^{80} 49$ Stat. 2002, 46 U.S.C. $\$ 1173$ (1952). 
according to plans and specifications approved by the FMB/Maritime Administration and the Secretary of the Navy, with particular reference to economical conversion into an auxiliary naval vessel or to other usefulness in time of national emergency; ${ }^{61}$ repairs to subsidized vessels must be performed within the continental limits of the United States, except in an emergency ${ }^{52}$ and a subsidized operator must conduct his business in the most economical manner possible..$^{53}$

Except with specific approval of the FMB or the Maritime Administration, a subsidized operator may not: (I) engage, through ownership, operation, or charter of any vessel, in the intercoastal or coastwise protected trades of the United States, either directly or through affiliates, nor hold any pecuniary interest in any person or vessel in such service; $;^{54}(2)$ operate unsubsidized vessels in competition with other American-flag lines or operate any unsubsidized vessel in the subsidized service of the operator ;5 (3) own, charter, or act as agent or broker for, or operate any foreignflag vessel competing with any essential American-flag service; ${ }^{56}$ (4) engage directly or indirectly in any auxiliary service connected with the operation of subsidized vessels, such as stevedoring, ship repairs, ship chandlering, tow boat, or kindred services; ${ }^{57}$ (5) effect any merger or consolidation, or directly or indirectly embark upon any new enterprise not connected with the business of shipping; $;^{58}$ or (6) dispose of any interest in the subsidy agreement or make any agreement for maintenance, management, or operation of the service by others. ${ }^{59}$

A subsidized operator, moreover, may not include more than $\$ 25,000$ for any official or employee of the company as a business expense in the computation of earnings for subsidy recapture purposes. Any salary payments in excess of $\$ 25,000$ must come from the operator's retained profits, computed in accordance with the Merchant Marine Act of $1936^{60}$ A subsidized operator must file, upon notice from the Iaritime Administration, balance sheets, profit and loss statements and other statements of financial operations, special reports, and memoranda of any facts and transactions which may affect the financial results obtained by the operator in the performance of his contract. In addition, the Maritime Administration is authorized to examine and audit the books, records, and accounts of the operator and its affiliates whenever it deems this necessary or desirable. ${ }^{61}$

An American operator receiving operating subsidy aid must also agree to the establishment of reserve funds to provide for replacement and acquisition of ships, prompt payment of his obligations to the United States, and continued maintenance

${ }^{61} 49$ Stat. 2007,46 U.S.C. $\$$ II 80 (1952).

52 Stat. 2004, 46 U.S.C. $\$ 1176$ (1952).

s3 Ibid.

${ }^{52} 49$ Stat. 2012, 46 U.S.C. $\$ 1223$ (1952).

${ }^{55} 49$ Stat. 2012, 46 U.S.C. \$ 1222 (1952).

${ }^{50} \mathrm{Ibid}$.

${ }^{57} 49$ Stat. 2012, 46 U.S.C. $\$ 1221$ (1952).

${ }^{58} 49$ Stat. 2007,46 U.S.C. $\$ 1178$ (1952).

s9 Ibid.

${ }^{60} 49$ Stat. 2012, 2005, 46 U.S.C. $\$$ I223, II77 (1952).

${ }^{01} 49$ Stat. 20II, 46 U.S.C. \$ I2II (1952). 
and operation of subsidized vessels. ${ }^{62}$ He must use articles, materials, and supplies produced in the United States, so far as practicable. ${ }^{63}$ No operating-differential subsidy may be paid for the operation of a vessel that is more than twenty years of age, except by special order of the FMB based on a finding of "public interest."64 The Board is authorized under section 30I of the Merchant Marine Act of 1936 to adopt minimum manning scales, minimum wage scales, and minimum working conditions for all officers and crews employed on all types of vessels receiving an operating-differential subsidy; ${ }^{65}$ and these provisions are incorporated into the subsidy contracts. In addition, section 302 of the Act provides that all officers of American-flag vessels must be American citizens, and that upon each departure from the United States of a cargo vessel in respect of which a construction or operating subsidy has been granted, all of the crew ("crew" including all employees of the ships) shall be citizens of the United States. ${ }^{66}$ Passenger vessels in respect of which a construction or operating subsidy has been granted must have a ninety per cent American-citizen crew, and the alien crewmen allowed, who may be employed only in the steward's department on the ship, must have evidence of legal admission to the United States for permanent residence.

\section{A. Recapture}

Section 606 of the Merchant Marine Act of 1936 provides that at the end of any ten-year period during which an operating-differential subsidy has been paid, if the net profit of the contractor on his subsidized vessels and services incident thereto during such period of time has averaged more than ten per cent per annum upon the contractor's capital investment necessarily employed in the operation of the subsidized vessels, the contractor shall pay to the United States an amount equal to one-half of such profits in excess of ten per cent per annum as partial or complete reimbursement for operating-differential subsidy payments during such recapture period. ${ }^{67}$ The amount of excess profit recaptured cannot in any case, however, exceed the amount of the operating-differential subsidy payments. As of December 3I, I957, the most recent date for which reliable figures are available, it is estimated that the total recapture liability of the subsidized operators was approximately nineteen per cent of the total operating-differential subsidy accrued.

No operating subsidy may be paid for the operation of a ship on a voyage on which it engages in coastwise or intercoastal trade. However, a subsidy may be paid in reduced amounts on certain voyages in foreign trade on which a ship carries cargo or passengers in intercoastal trade or to or from an island posession or island territory of the United States. ${ }^{08}$

49 Stat. 2005,46 U.S.C. 5 II77 (I952).

es 49 Stat. 2004,46 U.S.C. $\$ 1176$ (I952).

o6 49 Stat. 2003 , 46 U.S.C. $\$$ II75 (r952).

of 49 Stat. I992, 46 U.S.C. $\S$ II3I (1952).

${ }^{10} 49$ Stat. 1992, 46 U.S.C. $\$$ II32 (1952).

o7 49 Stat. 2004, 46 U.S.C. $\$$ II76 (I952).

${ }^{08} 49$ Stat. 2003,46 U.S.C. I175 (1952). 
Operating-differential contracts stipulate the minimum and maximum number of voyages to be made by the subsidized operators in each of the designated routes and services covered by the contract. All sailings are made on the basis of sailing schedules (including type and number of vessels, dates, ports of call, and other particulars) approved by the Maritime Administration. Sailings in excess of the maximum number specified can be made only with the prior approval of the Maritime Administration, and no subsidy is paid for such voyages. Failure of an operator to make a voyage is not deemed a breach of the operator's obligations under the contract if the cause of such failure is not within the control of the operator.

\section{B. Capital Reserve Fund}

Section 607 of the Merchant Marine Act of 1936 requires each American operator receiving operating-differential subsidy aid to establish a capital reserve fund and a special reserve fund and to make certain deposits therein. ${ }^{60}$ In his capital reserve fund, the operator must deposit: ( $x$ ) amounts equal to the depreciation (on a twentyyear life basis, or longer period in the case of certain reconstructed or reconditioned vessels), if earned, on all ships receiving an operating subsidy; (2) the proceeds of insurance and indemnities received on account of total loss of any ship receiving operating-differential subsidy aid and the proceeds from the sale or other disposition of any such ship; (3) such other amounts as the Maritime Administrator may determine to be necessary for replacement of subsidized vessels, but only if net profits on the subsidized vessels exceed ten per cent per annum of the capital necessarily employed on a cumulative basis from the date of the operating-subsidy contract; (4) interest or other income received on securities held in the capital reserve fund and the special reserve fund; and (5) interest paid on cash balances (including time deposits) in the capital reserve fund.

The capital reserve fund may only be used for the purchase of replacement ships or additional ships to be used on an essential foreign trade route, the reconstruction of ships, or for the liquidation of an indebtedness covered by notes secured by a mortgage on a subsidized ship. Temporary permission may be granted an operator to transfer to his general funds from the capital reserve fund those sums not needed to meet mortgage obligations, if the operator's general funds have become seriously depleted by reason of operating losses on ships receiving operating subsidy aid and if the funds in the operator's special reserve fund have become exhausted. If such a transfer is permitted, the operator is required to repay such transferred sums to the capital reserve fund as soon as his financial condition permits.

\section{Special Reserve Fund}

In his special reserve fund, the operator must deposit annually any profits (without regard to capital gains and losses) earned in the subsidized operations in excess of ten per cent, after taxes, of the operator's capital necessarily employed in the business. The profits available for deposit in the special reserve fund would be re-

\footnotetext{
${ }^{60} 49$ Stat. 2005,46 U.S.C. \$ II77 (I952).
} 
duced by the amount, if any, of profits required to be deposited in the capital reserve fund. Interest earned on cash balances in the special reserve fund must be deposited in that fund. From the special reserve fund, the operator may make only the following disbursements: (r) reimbursements of the operator's general funds for losses incurred in the operation of subsidized vessels and services; (2) payments due the United States for recapture of operating-differential subsidies, provided that the fund is not reduced below five per cent of capital necessarily employed; (3) transfers, with approval, of amounts to the operator's capital reserve fund; and (4) withdrawals, with approval, of amounts to the operator's general funds or for distribution, provided that recapture obligations to the Government are satisfied and that the special reserve fund is not reduced below five per cent of capital necessarily employed.

With the approval of the Maritime Administrator, an operator may make voluntary deposits in his capital or special reserve fund of any earnings otherwise available for distribution to stockholders. The Maritime Administration has adopted a policy limiting such voluntary deposits to amounts reasonably necessary to build up the funds in anticipation of future requirements for ship replacements. Ship-building costs, estimated amount of construction subsidy which will be payable, imminence of the replacement, and current status of the funds are all considered in determining whether a proposed voluntary deposit is reasonably necessary to provide funds for ship replacement.

Section 607 of the Merchant Marine Act of 1936 further provides that earnings deposited in operators' capital or special reserve funds, except earnings withdrawn from the special reserve funds and paid into the operator's general funds or distributed as dividends or bonuses, "shall be exempt from all Federal taxes." However, closing agreements of July 2r, I947 between the Commissioner of Internal Revenue and the subsidized operators have modified that exemption. Under these agreements, earnings from subsidized and nonsubsidized operations, as well as capital gains, are treated, to the extent deposited in reserve funds, as "tax deferred." The term "tax deferment" as used in the closing agreements means (a) that earnings deposited are not taxed in the year of deposit; (b) that such nontaxed earnings, when used in the acquisition of vessels, are not included in the tax basis of vessels either for purpose of tax depreciation or for determining gain or loss, and are not included in invested capital; and (c) that if amounts are withdrawn from the reserve funds and are paid into the operator's general funds or distributed as dividends or bonuses, the earnings withdrawn are taxable as if earned in the year of such withdrawal.

Section 604 of the Merchant Marine Act of 1936 authorizes the FMB, after consultation with the Secretary of State, to grant such additional subsidy as it determines to be necessary if it finds for any particular foreign trade route that the operatingdifferential subsidy is inadequate to offset the effect of governmental aid paid to 
foreign competitors. ${ }^{70}$ To date, no such additional countervailing subsidy assistance has been granted.

Aids for Private Financing-Titue Eleven of the Merchant Marine Act of 1936

Title eleven provides authority for government insurance of ship mortgages and short-term loans to finance ship construction. ${ }^{71}$ The Maritime Administration, upon application by the mortgagor, is authorized to insure loans or mortgages securing loans if they are made to aid in financing the purchase of (including payment of loans previously made to finance) or reimbursing the mortgagor for expenditures previously made for the construction, reconstruction, or reconditioning of vessels. These vessels must, however be owned by American citizens and used by them in the foreign or domestic commerce of the United States, on the Great Lakes, bays, sounds, harbors, or inland lakes of the United States, or in the fishing trade or industry. The term "vessel" is defined to include all types of passenger, cargo, and combination passenger-cargo vessels, tankers, tugs, towboats, barges, and dredges documented under the laws of the United States, and fishing vessels owned by American citizens. The Maritime Administration may also make commitments to insure mortgages or loans eligible for title eleven insurance.

The faith of the United States is pledged to the payment of interest on and the unpaid balance of each mortgage and loan insured under title eleven. In the event of a default under the loan or mortgage which is not remedied within thirty days, the lender or mortgagee has the right to tender to the Maritime Administration an assignment of the mortgage or loan and the obligations connected therewith, and to demand payment of the insurance. Within thirty days from the date of any such demand, the Maritime Administration is required to accept the assignment and promptly pay the full loan or mortgage insurance in cash; the Maritime Administration then succeeds to the rights of the lender or mortgagee. Prior to 1958, prompt payment depended upon the amount of moneys held in the Federal Ship Mortgage Insurance Fund created by title eleven and upon congressional appropriations. The Eighty-fifth Congress, however, amended title eleven to authorize borrowing funds from the Secretary of the Treasury for payment of title eleven insurance if the moneys in the Federal Ship Mortgage Insurance Fund are not sufficient. ${ }^{72}$

A mortgage or a loan insured under title eleven must have a mortgagee or lender approved by the Maritime Administration and a mortgagor or borrower approved as possessing the ability, experience, financial resources, and other qualifications necessary to the adequate operation and maintenance of the vessel. In addition, the property or project with respect to which the mortgage or loan is to be executed must be found to be economically sound.

${ }^{70} 49$ Stat. 2003,46 U.S.C. $\S$ II74 (I952).

${ }^{71} 52$ Stat. 968 (1938), 46 U.S.C. $\$ 5$ I271-79 (1952).

7272 Stat. 358 , 46 U.S.C.A. $\$$ r 275 (b) (Supp. 1958). 
Prior to 1956, the Maritime Administration could only insure ninety per cent of the unpaid principal of loans or advances made to finance the construction, reconstruction, or reconditioning of vessels. The Eighty-fourth Congress, however, amended title eleven to provide roo per cent government insurance of principal and interest for qualified ship mortgages and loans. ${ }^{73}$ This amendment has greatly facilitated private financing of merchant vessel construction and has enabled the Government to follow a general policy of insuring under title eleven, rather than financing through government loans, the subsidized operator's vessel replacement costs. As of January I, 1959, insurance was in effect on thirty-two new vessels and major reconstruction projects, with a total mortgage coverage of over $\$ 244,000,000$.

Except for mortgage insurance on the construction of certain vessels which are not being built with construction-subsidy aid and which possess national defense features making them eligible for an 87.5 per cent loan under section 509 of the Merchant Marine Act of $193^{6,74}$ in which case an eligible mortgage may cover 87.5 per cent of "actual cost," a loan or mortgage to be eligible for title eleven insurance may not exceed seventy-five per cent of the actual cost (as determined by the Maritime Administration) of the vessel construction, reconstruction, or reconditioning. The period of an insured loan or mortgage is limited to twenty years, which throughout the statutes is considered the "economic life" of ships. The annual interest charge may not exceed five per cent, or six per cent if the Maritime Administrator finds that in certain areas or under special circumstances the mortgage or lending market demands it.

In general, title eleven is not available for insuring mortgages which refinance, wholly or partly, existing mortgage indebtedness. However, the Maritime Administration may insure an eligible mortgage which refunds a previous title eleven mortgage at a lower interest rate; and it may, in certain instances and to a limited extent, insure refinancing in connection with mortgages additionally covering new construction, reconditioning, or reconstruction. The Maritime Administration is authorized to charge and collect amounts aggregating not more than one-half of one per cent of the original principal amount of the mortgage or loan to be insured; this sum is for the investigation of applications for insurance, the issuance of commitments, and the appraisal and inspection of vessels. The Maritime Administration also collects a premium for the insurance of mortgage and loans under title eleven. In the case of an insured mortgage, the premium must be not less than one-half of one per cent annually nor more than one per cent annually of the average principal amount of the mortgage outstanding; in the case of insured loans, the premium must. be not less than one-quarter of one per cent annually nor more than one-half of one per cent annually of the average principal amount of the loan outstanding. All moneys received under any of the provisions of title eleven must be deposited in the Federal Ship Mortgage Insurance Fund.

\footnotetext{
73 yo Stat. 1087 (I956), 46 U.S.C.A. \$ ז27r (Supp. x958).
}

74 Stat. 2000,46 U.S.C. $\$$ II59 (1952). 
VIII

\section{Other Government Aids to ShIpping}

A. Charter

In addition to the chartering of reserve fleet vessels discussed previously, section $7 \mathrm{I} 4$ of the Merchant Marine Act of 1936 provides that if the Maritime Administration finds that any essential trade route cannot be successfully developed and maintained with modern vessels under private operation by an American citizen with Americanflag vessels without government financial aid other than that authorized under titles five and six of the Act, the Administration is authorized to have constructed, in private shipyards or in navy yards, the vessel or vessels of types deemed necessary for such trade route, and to bareboat charter such new vessel or vessels to the American-flag operator established on such trade route. ${ }^{75}$ This authority has not been exercised recently. The charters under this section may contain an option to the charterer to purchase the vessel within five years of its delivery to him, upon terms generally similar to those provided in title five. Section 705 of the Act authorizes the bareboat charter of certain Government-owned vessels to American citizens who agree to operate them on a designated trade route. ${ }^{76}$ Awards under section 705 may be made only after advertisement and competitive bidding.

Section 707 of the Merchant Marine Act of 1936 authorizes the FMB to grant an operating-differential subsidy on vessels chartered from the Government upon the same terms and conditions and subject to the same limitations and restrictions, where applicable, as apply with respect to privately-owned vessels. ${ }^{77}$ As of January I, 1959, only nineteen of the $3^{12}$ vessels operating under subsidy contracts were Governmentowned; the rest were owned by the operator. It should be pointed out, also, that most of these vessels have been traded in to the Government in connection with the operator's replacement program and are only being temporarily operated by their former owners under a use-agreement provision of the trade-in contract under section 5 10 of the Act. ${ }^{78}$ Also among the nineteen are some experimental vessels chartered from the the Government.

\section{B. Experimental Vessels}

The construction, outfitting, and preparation for operation-including training of qualified personnel-of a nuclear-powered merchant ship capable of providing shipping services on routes essential for maintaining the flow of foreign commerce of the United States is authorized by section 716 of the Merchant Marine Act of 1936 , as amended, ${ }^{79}$ and the vessel is presently under construction. Section 715 of the Act authorizes the Maritime Administration, for the purpose of practical development, trial, and testing, to operate, under general agency agreements or bareboat charter,

\footnotetext{
${ }^{35} 49$ Stat. 2011, 46 U.S.C. $\$ 1204$ (I952).

${ }^{76} 49$ Stat. 2009, 46 U.S.C. $\$ 1195$ (1952).

${ }^{77} 49$ Stat. 2009, 46 U.S.C. $\$ 1197$ (1952).

${ }_{78} 53$ Stat. $x 183$ (1939), 46 U.S.C. \$ I 60 (I952).

7970 Stat. 731 (1956), 46 U.S.C. $\$ 1206$ (Supp. V, 1958).
} 
vessels which have been constructed, reconditioned, or remodeled for experimental or testing purposes. ${ }^{80}$ Such operation can be in the foreign or domestic commerce of the United States or for the account of any agency or department of the United States.

\section{War Risk Insurance}

Title twelve of the Merchant Marine Act of 1936 , as amended, the "Marine War Risk Insurance Act," is standby legislation which authorizes the Maritime Administration, with the approval of the President, to provide war risk and certain marine and liability insurance for protection of vessels, cargoes, and crews and personal effects when commercial insurance cannot be obtained on reasonable terms and conditions. ${ }^{81}$ Arrangements have been made to have war risk insurance immediately available and in operation, and a full wartime insurance program can quickly be put into effect in case of need. Title twelve, by its terms, is to expire on September 7 , $x 965$.

\section{Cargo Preference for American Vessels}

Section 90I of the Merchant Marine Act of 1936, provides that officers and employees of the United States traveling on official business overseas, or to or from any of the possessions of the United States, shall travel and transport their personal effects on ships registered under the laws of the United States where such ships are available and unless the necessity of their mission requires the use of a ship under a foreign flag. ${ }^{82}$

Section gor also provides that whenever the United States shall procure, contract for, or otherwise obtain for its own account, or shall furnish to or for the account of any foreign nation without provision for reimbursement, any equipment, materials, or commodities, within or without the United States, or shall advance funds or credits or guarantee the convertibility of foreign currencies in connection with the furnishing of such equipment, materials, or commodities, the appropriate agency or agencies shall take such steps as may be necessary and practicable to assure that at least fifty per cent of the gross tonnage of such equipment, materials, or commodities (computed separately for dry bulk carriers, dry cargo liners, and tankers) which may be transported on ocean vessels shall be transported on privately-owned American-flag commercial vessels, to the extent such vessels are available at fair and reasonable rates, in such manner as will insure a fair and reasonable participation of American-flag commercial vessels in such cargoes by geographic areas. This fifty-fifty cargo preference may be temporarily waived, however, whenever Congress or the President or the Secretary of Defense declares that an emergency exists justifying such waiver and notifies the appropriate agency or agencies. The large amounts of cargo moved under the mutual aid laws have made cargo preference a very important factor in

${ }^{80} 70$ Stat. 531 (1956), 46 U.S.C. $\$ 1205$ (Supp. V, r958).

${ }^{81} 64$ Stat. 773 (I950), 46 U.S.C. $\$ \$$ I $28 \mathrm{I}-94$ (1952).

${ }^{82} 49$ Stat. 2015, as amended, 70 Stat. 187 (I956), 46 U.S.C. § I24I (Supp. V, 1958). For a more extended discussion of cargo preference policies and practices, see Olson, Cargo Preference and the American Merchant Marine, infra pp. 82-ro5. 
support of American-flag tramp shipping. Section gor (b) specifically provides that it is in addition to Public Resolution 17 of the Seventy-third Congress, ${ }^{83}$ which generally requires exclusive carriage in American vessels of agricultural or other exports financed by loans from government instrumentalities, unless the Maritime Administration certifies that American vessels are not available in sufficient numbers, or in sufficient tonnage capacity, or on necessary sailing schedule, or at reasonable rates.

\section{E. Training}

The Maritime Administration is authorized to establish and maintain the United States Maritime Service as a voluntary organization for the training of American citizens to serve as licensed and unlicensed personnel on American merchant vessels; and under section $2 \times 6$ of the Merchant Marine Act of 1936, as amended, the Administration also maintains the United States Merchant Marine Academy located at Kings Point, Long Island, New York. ${ }^{84}$ This institution is fully-accredited and offers a four-year course leading to a license as an officer in the United States Merchant Marine, a commission as ensign in the United States Naval Reserve, and a Bachelor of Science degree. The Eighty-fifth Congress codified the laws providing for federal assistance in the form of financial aid, vessel loans, and detail of certain federal officers, to state and territorial maritime academies or colleges for the training of merchant marine officers. ${ }^{85}$

\section{F. Other Governmental Activities}

A number of other government agencies in addition to the Maritime Administration and the FMB have duties in connection. with the merchant marine. The United States Coast Guard, for instance, investigates all marine casualties and surveys American-flag ships for the purpose of determining. whether they are seaworthy and conform to safety-of-life-at-sea requirements. ${ }^{86}$ The Public Health Service of the Department of Health, Education, and Welfare regulates sanitary conditions on ships. ${ }^{87}$ The Customs Office of the Treasury Department administers the documentation and registration of American-flag vessels, as well as collecting taxes and duties on cargo. ${ }^{88}$.

\section{IX}

\section{Conclusion}

The need for a strong American merchant marine to aid in developing United States domestic and foreign commerce and as an arm of our national defense is as urgent todáy as at any time in our history.

Some of the benefits from the commercial viewpoint of our merchant marine policies derive from the fact that only the American-flag carriers have any ties inducing

8348 Stat. 500 (1934), I5 U.S.C. \$6I6a (1952).

s4 52 Stat. 965 (1938), as amended, 7o Stat. 25 (1956), 46 U.S.C. $\$ 1126$ (Supp. V, 1958).

8572 Stat. 622 (1958), 46 U.S.C.A. \$ 1381 (Supp. 1958).

${ }^{80} 60$ Stat. Iog7 ( 1946 ); 46 U.S.C. $\$ 660 a^{\prime}$ (1952)...

${ }^{8 \pi} 32$ Stat. 712 (1902); 46 U.S.C. $\$ 654^{\circ}$ (1952): .

${ }_{38}^{88}$ Stat. 136 (1906), 46 U.S.C. $\$ 260$ (1952). 
them to promote and develop America's foreign trade. Foreign-flag carriers serve our trade to suit their economic convenience, because it is profitable-sometimes to get dollar exchange, sometimes for other reasons; their reasons are those of self-interest and are only indirectly concerned with our economic welfare. As a consequence, their ships enter and withdraw from our trade at will. For example, various lines which operated foreign-flag chartered ships discontinued services when the charter market rose to abnormal heights, while some foreign-flag-owned ships which had been operated as liners over our routes were withdrawn and transferred to the more profitable world tramp market. Of course, in times of war or economic crisis, this withdrawal of foreign flag tonnage is greatly accentuated. Inflated costs may be another factor tending to this result. Without America's sound maritime policy, this could leave important segments of our industry without means of transporting products to overseas markets or obtaining vital raw materials. American foreign commerce and the American shipper are protected by the regular service with modern vessels required by operating-differential subsidy contracts. Established pan specific essential trade routes, the American-flag operators tailor their operations, equipment, and service to the needs of their trade, insuring a continued flow of our vital import and export commerce.

The need for a strong American merchant marine from the viewpoint of national defense was recently stated by the Secretary of the Navy. He said: ${ }^{89}$,

A large, modern, and well-balanced American merchant marine is positively vital to our defense planning, as, without it, in time of war, neither the military effort nor the war economy of our Nation could be supported. The need for the development and maintenance of an adequate merchant marine was envisioned and expressed by a farsighted Congress 2I years ago. This need, from our point of view, is even more vital today.

All of us are familiar with the life-sustaining role played by our merchant marine in World War II, a large-scale example of conventional warfare. Few could doubt its importance in any future warfare of a similar nature, but a number have questioned its importance in the event of a nuclear war.

Should a nuclear war be forced upon us, the military envisions that there would be an initial rapid and devastating exchange of weapons, during which period safety of shipping would be paramount. Shipping would be dispersed, and no attempts made to deliver other than truly vital cargo to any major ports. In the wake of widespread nuclear destruction, the American merchant marine would assume a vital role in the hauling of the sinews of war and sustenance. This concept is not confined to our Department of Defense; it is internationally endorsed.

The FMB and the Maritime Administration keep under constant review all aspects of the situation of our American merchant marine and the factors affecting it, and endeavor by every means to achieve the objectives of the national shipping policy declaration, as set forth in title one of the Merchant Marine Act of 1936.

${ }^{80}$ Hearings Before the House Committee on Merchant Marine and Fisheries, on Study of Vessel Transfer, Trade-in, and Reserve Fleet Policies, 85th Cong., Ist Sess. 630-3I (1957). 